PEDRO DOLABELA CHAGAS
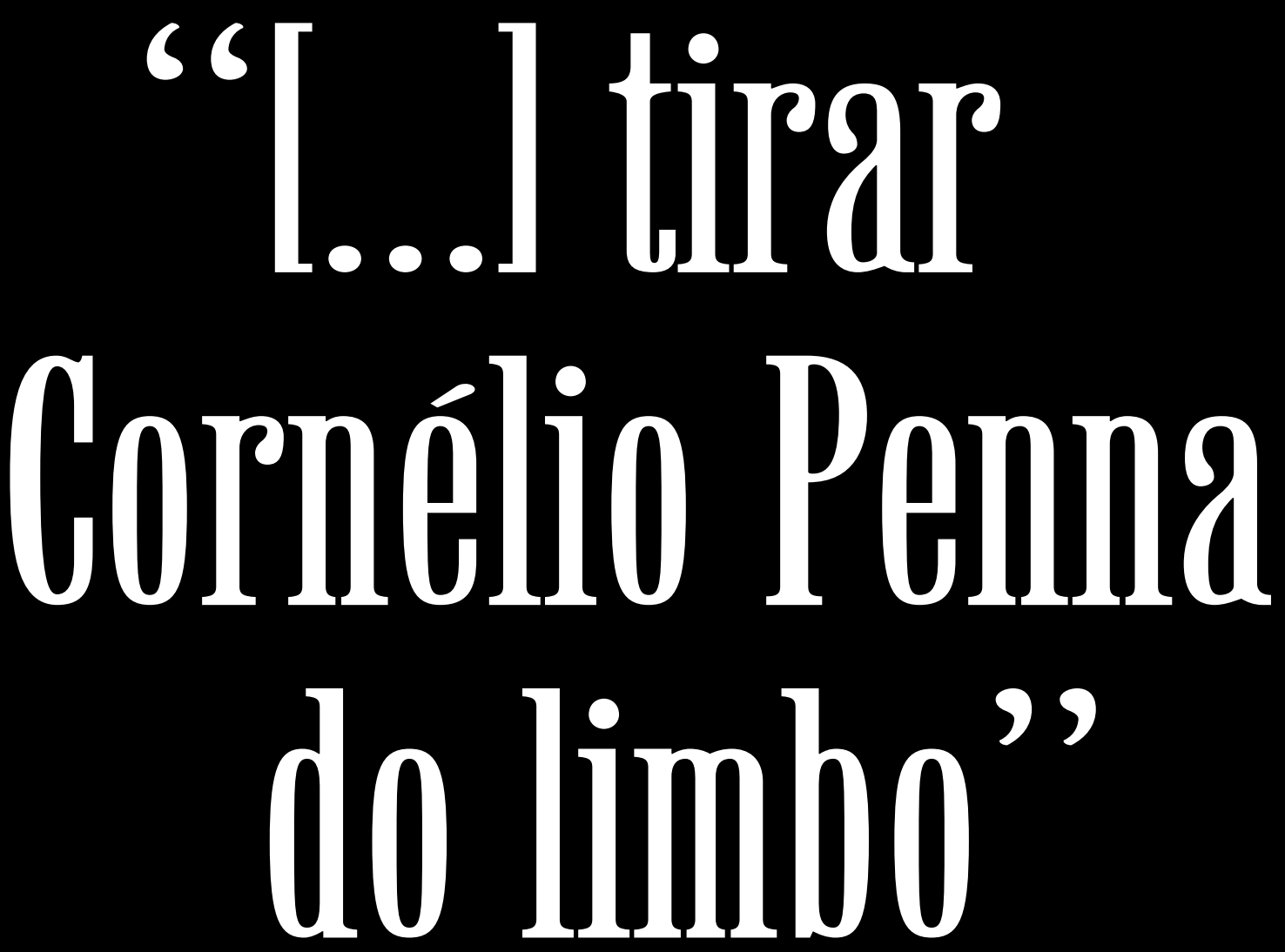

0 relançamento da obra de Luili Costa Lima sobre o escritor fluminense 


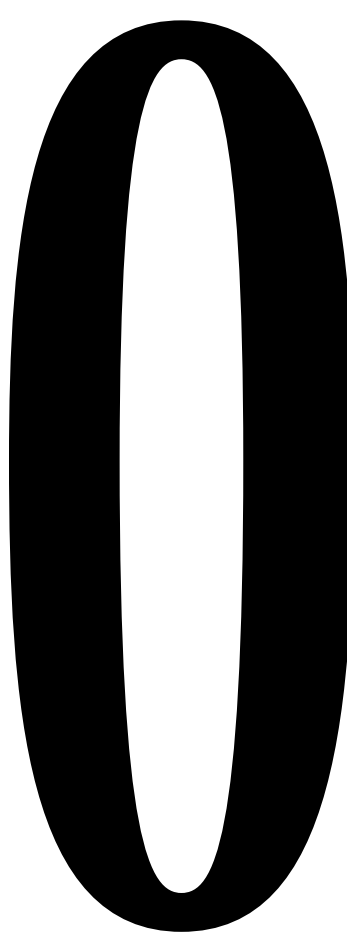

que constitui uma boa crítica literária? Sabemos tratar-se de uma atividade que não obedece a regras ou modelos tutelares, e que depende, além do mais, da intuição criativa do seu autor. Mas como age essa intuição? Fosse a sua criatividade poética, então a crítica se tornaria um gênero literário, o que obscureceria a sua diferenciação - a sua especificidade - quanto às demais formas de discurso, obscurecendo com isso também a sua função social. Porém a criatividade do crítico não é análoga à do poeta, mas sim à do cientista ou do investigador. O que lhe interessa não é produzir uma obra, um fato novo, mas sim colocar uma pergunta para um fato já existente. O desafio é o de encontrar uma pergunta criadora (aquela que, preservando da forma mais fidedignamente possível o fato analisado, consegue colocá-lo sob uma nova luz). Ora, se passados 29 anos a Editora da UFMG decidiu relançar O Romance em Cornélio Penna - de autoria de Luiz Costa Lima e outrora intitulado A Perversão do Trapezista -, é de supor que as perguntas ali lançadas ao escritor fluminense continuem férteis, atuais. Expô-las é o objetivo desta resenha.

Essa nova edição promove a simultaneidade de duas perguntas separadas por uma distância de 29 anos. Em 1976, Costa Lima leu a obra de Cornélio Penna através da combinação de uma matriz formal estruturalista (principalmente lévi-straussiana) com uma análise do substrato sócio-histórico

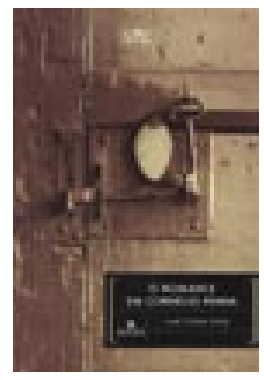

0 Romance em Cornélio Penna, de Luiz Costa Lima, Belo Horizonte, Editora da UFMG, 2005, 232 pp.

\section{PEDRO DOLABELA}

CHAGAS é doutorando pela UERJ e pela UFMG e professor da Unipel, em Pedro Leopoldo (MG). 
subjacente à matéria ficcional. Com isso ele pretendia compreender as linhas de estruturação responsáveis, por exemplo, pela enorme tensão e violência presentes em $A$ Menina Morta (indiscutivelmente a melhor obra de Cornélio). Um dos resultados desse procedimento analítico está na cartografia da "economia afetiva" que orientava a circulação das personagens pelo espaço físico da fazenda, com a elaboração de um "mapa" a tornar visível (concreto, palpável) o jogo de forças (invisível, abstrato) desencadeado pela morte da criança. Entretanto, para Costa Lima esse construto formal adquire sentido apenas quando tais forças são compreendidas em seu fundamento sócio-histórico, que, em A Menina Morta, não é nenhum outro senão o cotidiano da escravidão. Somente aí é atingida a meta de, através do formalismo estruturalista (que investiga a materialidade do texto), trazer à tona a "miséria da nossa formação" histórica (que a obra em questão faz apenas sugerir).

Em 2005 essa análise continua constituindo o corpo do livro. Ocorre que, no "Prefácio à 2 a edição", a investigação do locus social da forma romanesca é precedida, e (re)atualizada, por aquela que é provavelmente a principal pergunta concernente à obra de Cornélio: por que razões ele não é lido ou, pior, é quase desconhecido pelo leitor brasileiro? Tal indagação revolve o conteúdo de 1976 sob uma luz não prevista pela primeira edição, que lhe dá um sentido novo: assim, quem ler o "Prefácio" com atenção acabará por ler também um livro um pouco diferente daquele de 29 anos atrás.

Para falar sobre os motivos da marginalidade do romancista, o crítico dá uma nova inflexão à questão do mito: ao passo que o Costa Lima dos anos 70 pensava o mito qua mito (como um gênero narrativo distinto, porém vizinho ao romance), agora o caso é o de confrontar A Menina Morta com um mito em particular, a saber, o da "democracia racial" brasileira. A comparação com Casa-grande \& Senzala é nuclear para a leitura do romance de Cornélio como um contramito: enquanto o clássico de Freyre trazia uma visão apaziguadora da violência racial no processo colonizador no Brasil, A Menina Morta encena essa violência na sua crueza mais absoluta e aterrorizante. Em contraposição à amenidade que em Freyre é tão análoga ao entendimento que os brasileiros têm de si mesmos (eque explica, ao menos em parte, a sua grande fortuna crítica), em Cornélio o terror implode a domesticação da história propugnada pelo mito da "democracia" - nem que para isso a própria forma romanesca tivesse que ser reinventada.

Pois o estranhamento quanto a AMenina Morta antecede o impacto causado pela sua tematização da matéria histórica. Segundo Costa Lima, a busca por uma representação crua da violência instaurou nos romances de Cornélio um "clima fantasmal" ou "de pesadelo", uma "quase-irrealidade" que quebrava as convenções que fizeram do romance realista um veículo de equilíbrio das tensões sociais (a projetar uma continuidade, ainda que tensa, das grandes instituições). Neles, o real não era enunciado (lembremo-nos do cortiço de Azevedo, com o caráter quase literal da sua crítica sociopolítica), mas sim reencenado no seu cotidiano traumático. Se o horror não nos é enunciado (por um narrador onisciente, por exemplo), mas sim vivido pelas personagens que nele estão imersas, o leitor fica diante de uma série de silêncios, e para que o tema da obra-prima de Cornélio se "torne presente", ele deve ser sentido, vivenciado, pois não será "exposto" ou "apresentado" ao leitor. Um tal tipo de experiência estética carrega grandes dificuldades, pois exige um receptor maduro. Não espanta, portanto, que o autor não tenha alcançado sucesso de público.

Através da análise formal e da investigação da escassez da sua recepção, Costa Lima trouxe a ambiência "fantasmática" dos romances de Cornélio Penna para o solo concreto da nossa experiência histórica, inaugurando uma legibilidade possível para um dos nossos grandes romancistas. Retomando as palavras do seu novo "Prefácio", é de esperar que esse esforço de fato ajude "a tirar Cornélio Penna do limbo em que sempre esteve". 